\title{
Effect of microalgal food on the sex reversal of Hippolyte inermis (Crustacea: Decapoda)
}

\author{
Valerio Zupo* \\ Stazione Zoologica ‘A. Dohrn' di Napoli, Laboratorio di Ecologia del Benthos, Punta San Pietro, 80077 Ischia (Naples), Italy
}

\begin{abstract}
The effect of diatoms of the genus Cocconeis on the sex reversal of the shrimp Hippolyte inermis Leach was examined in the laboratory. Randomised experiments were carried out to investigate the functional response of shrimps to various diets. The benthic diatom Cocconeis neothumensis was offered, alternatively, during the larval phase and during the postlarval phase, and the results obtained with shrimps produced by individual females were compared. Results demonstrated that diets based on green alga Enteromorpha sp. or dry commercial food did not influence the normal protandric development, as most shrimps at sexual maturation were males. Conversely, diets containing C. neothumensis did influence the protandric development, as most shrimps at sexual maturation were females and the sex ratio was significantly different from that obtained with diets not containing C. neothumensis. These results provide an explanation of the patterns observed in the field, and are in accordance with the seasonal abundances of diatoms in the leaf stratum of Posidonia oceanica.
\end{abstract}

KEY WORDS: Diatom $\cdot$ Shrimp $\cdot$ Sex change $\cdot$ Adaptation $\cdot$ Feeding

\section{INTRODUCTION}

The shrimp Hippolyte inermis Leach lives in seagrass meadows (Zariquiei Alvarez 1968, Guillen Nieto 1990, Gambi et al. 1992) and undergoes a process of protandric sex reversal (Yaldwyn 1966), well demonstrated by previous investigations (Reverberi 1950, Veillet et al. 1963). However, it has been demonstrated that not all individuals in natural populations undergo the sex reversal process. Small females, presumably derived from direct differentiation, were also found in Posidonia oceanica meadows (Zupo 1994). Two reproductive periods that are synchronised with the seasonal growth cycle of $P$. oceanica (Buia et al. 1992) were detected in natural populations of the shrimp (Zupo 1994). The first period occurs in spring with the appearance of both males and females; the second period occurs in fall, with the appearance of males which then undergo sex reversal during the next year, after the following spring reproduction (Veillet et al. 1963). Small ('beta') females exhibit maximum abundance in association with blooms of epiphytic diatoms

*E-mail: vzupo@alpha.szn.it
(Mazzella \& Ott 1984); large females ('alpha' females, derived from sex reversal) first develop as males in September, during the period of minimum field abundance of epiphytic diatoms.

Immature individuals of this opportunistic, herbivorous shrimp (Zupo \& Fresi 1985) feed on the most common epiphytes of Posidonia oceanica leaves, predominantly on microalgae, macroalgae, dinoflagellates of the genus Prorocentrum and some animals (e.g. Bryozoans, Foraminiferids). Adult individuals feed on microalgae, macroalgae and a few animal organisms. This diet pattern is common to several species of natantian decapods (Regnault 1969c, Nelson 1981, Gutiérrez-Yurrita et al. 1998). The diet of beta females is significantly different from that of males in the field (Zupo \& Mazzocchi 1998). The gut contents of these females are dominated by some species of benthic diatoms, e.g. Cocconeis spp. that are particularly abundant (Mazzella et al. 1989) in the period of their development (spring). In contrast, the gut contents of alpha females are characterised by a lower abundance of diatoms; Cocconeis spp. in particular, are less abundant in the field and in gut contents of alpha females (Zupo \& Mazzocchi 1998) in the period of their development (autumn). 
The observed dietary differences and the significant relationships of the shrimp life cycle (alternation of alpha and beta females) with the seasonal pattern of abundance of diatoms in the leaf stratum of Posidonia oceanica (Buia et al. 1992), suggested the hypothesis of an influence of microalgal food on the sex reversal mechanism of this species (Zupo 1994). A laboratory experiment was devised and carried out to test the hypothesis that diatoms of the genus Cocconeis may influence the sex reversal of $H$. inermis (Zupo 1994), promoting the development of small females directly differentiated.

\section{MATERIAL AND METHODS}

Hippolyte inermis specimens were collected in Lacco Ameno (Bay of Naples, Italy), in the same site where samples were previously obtained for the investigation of the shrimp life cycle (Zupo 1994) A $400 \mu \mathrm{m}$ mesh net (diameter $50 \mathrm{~cm}$ ) was towed horizontally above Posidonia oceanica leaves at depths between 5 and $15 \mathrm{~m}$. Two sampling seasons, April and September 1997, were chosen for sampling and rearing experiments, corresponding to the reproductive peaks of this species. Each sample was quickly sorted on board the boat to identify $H$. inermis specimens. In the laboratory, the collected individuals were examined under a dissecting microscope to confirm their identification (Zariquiei-Alvarez 1968), and their total length (tip of the rostrum, to the posterior medial notch) was measured. Their sex was determined (Fernández-Munoz \& García-Raso 1987, d'Udekem d'Akoz 1996), and specimens in good condition were divided into 20 couples.

Individual couples were reared in $1000 \mathrm{ml}$ flasks, containing $800 \mathrm{ml}$ of $0.25 \mu \mathrm{m}$ filtered seawater, enriched with a culture of the rotifer Brachionus plicatilis ( 2 ind. $\mathrm{ml}^{-1}$ ). Flasks were reared in a thermostatic chamber, at a fixed temperature of $18^{\circ} \mathrm{C}$, with a photoperiod of $12 \mathrm{~h}$ and an irradiance of $400 \mu \mathrm{E} \mathrm{m} \mathrm{m}^{-2} \mathrm{~s}^{-1}$. Shrimp food (Tetra AZ300 Artificial plankton for shrimps Type 1; Tetra Werke, Germany; 0.5 g) was added daily to each flask. Flasks, protected by gauze plugs to limit evaporation, were gently aerated. The medium in each flask was filtered daily through a $0.25 \mu \mathrm{m}$ mesh net and replaced with fresh seawater enriched with rotifers; nets were checked under a stereomicroscope for the presence of larvae.

Culture of plant and animal items. Culture dishes were maintained in the same thermostatic chamber hosting the experimental shrimps to obtain sufficient amounts of plant and animal items to be fed to larvae and postlarvae. Monoclonal cultures of benthic diatoms available in the 2 periods of shrimp reproduction
(Cocconeis neothumensis var. marina, Nitzschia sp.) were isolated from Posidonia oceanica leaves (Mazzella \& Buia 1989). Diatoms were reared in Petri dishes (50 mm diameter) at $18^{\circ} \mathrm{C}$ in a sterilised $\mathrm{F} 2$ medium (Sigma Chemical), and were transferred every $5 \mathrm{~d}$. Monoclonal cultures of macroalgae (Enteromorpha sp.) were also isolated from $P$. oceanica leaves and were reared in Petri dishes (diameter $10 \mathrm{~cm}$ ) at $18^{\circ} \mathrm{C}$, in a sterilised Provasoli (1963) medium. In addition, monoclonal cultures of phytoplankton Dunaliella sp., Chlamydomonas sp. and Isochrysis $\mathrm{sp}$. were reared in $500 \mathrm{ml}$ flasks at $18^{\circ} \mathrm{C}$, using a sterilised $\mathrm{K}$ (Keller et al. 1987) medium with transfers every $10 \mathrm{~d}$. Monoclonal cultures of Brachionus plicatilis were reared in $500 \mathrm{ml}$ flasks at $18^{\circ} \mathrm{C}$, in $400 \mathrm{ml}$ of $0.45 \mu \mathrm{m}$ filtered seawater enriched with a phytoplankton diet (1/3 Dunaliella spp., 1/3 Isochrysis spp., 1/3 Chlamydomonas spp., at a final cell concentration of about $10^{5}$ cells $\mathrm{ml}^{-1}$ ), transferred every 7 to $8 \mathrm{~d}$. Artemia salina cysts (New Technology, Bryne Shrimp, NT Laboratories Ltd) were reared in prefiltered $(0.45 \mu \mathrm{m})$ seawater at $28^{\circ} \mathrm{C}$, and freshly hatched nauplii were fed to shrimp larvae.

Experimental procedures. Larval phase: Each feeding experiment consisted of a larval and a postlarval phase. The complete experimental plan called for 3 replicates for each of 4 postlarval feeding treatments (described below). Newly hatched larvae from each female used were counted and divided using a Pasteur pipette into 2 groups of 100 individuals, and immediately transferred to $1000 \mathrm{ml}$ flasks containing $800 \mathrm{ml}$ of filtered $(0.45 \mu \mathrm{m})$ seawater. Five zoeal stages were observed, as described by Le Roux (1963). In flasks used to rear larvae for 3 of the postlarval treatments, the seawater was enriched (Le Roux 1963, Regnault 1969a) with Artemia salina freshly hatched nauplii (1 ind. $\mathrm{ml}^{-1}$ ), Brachionus plicatilis (3 ind. $\mathrm{ml}^{-1}$ ), Dunaliella sp. (10000 cells ml $\left.{ }^{-1}\right)$, Nitzschia sp. (14000 cells $\mathrm{ml}^{-1}$ ) and compound shrimp food (Tetra AZ300 Type 000; Tetra Werke, Germany; $150 \mathrm{mg}$ per $800 \mathrm{ml}$ ). In the set of flasks used to rear larvae for the fourth postlarval treatment $(\mathrm{GA}(\mathrm{C}))$, Nitzschia sp. was replaced by Cocconeis neothumensis during the larval phase (14000 cells ml ${ }^{-1}$ ) to check the influence of this diatom on the larval development (Fig. 1).

An experiment was started when 6 females produced at least 200 larvae each, to be divided into flasks for the 4 treatments (Fig. 1). The larvae produced by other females, in lower abundance, were discarded. In September, when the mean size of females was lower than in April, only 2 replicates of the experiment were performed, as it was impossible to obtain, contemporaneously, 6 females producing at least 200 larvae each. The September experiment was therefore conducted on 800 larvae produced by 4 females (Replicates 1 and 2, Fig. 1). 
Water in each flask was aerated by means of an airstone (Rice \& Williamson 1970). Flasks for larval culture were reared in the same thermostatic chamber, on the same surface where adult individuals were reared, at $18^{\circ} \mathrm{C}$ and were protected by gauze plugs. The water temperature and the other abiotic factors (irradiance, photoperiod, salinity, $\mathrm{pH}$, oxygen and ammonium concentration) were maintained constant during both periods of experiment. All experimental flasks were placed in a single row, at the same level in the chambers, to guarantee identical experimental conditions for all the replicates. Every 2 d, larvae were gently filtered through a net $(0.25 \mu \mathrm{m}$ mesh), counted and transferred to new flasks with identical fresh culture media. At the same time interval, 2 individuals were collected and fixed in $4 \%$ glutaraldehyde, to be measured using an electronic system of image analysis (Image Pro Plus, Media Cybernetics).

The number of larvae decreased during the experimental period, due both to natural mortality and the sampling of individuals at $2 \mathrm{~d}$ intervals. The larval growth phase lasted about $25 \mathrm{~d}$ and was checked every $2 \mathrm{~d}$, to confirm the settlement of all individuals as completely developed postlarvae.

Postlarval phase: The postlarval phase of the feeding experiment started when all larvae settled. The 4 diet treatments for the postlarvae were (1) GADF: green alga Enteromorpha sp. + dry food (Tetra AZ300 Artificial plankton for shrimps Type 000); (2) DF: dry food (Tetra AZ300 Artificial plankton for shrimps Type 000); (3) DFC: Cocconeis neothumensis + dry food (Tetra AZ300 Artificial plankton for shrimps Type 000);

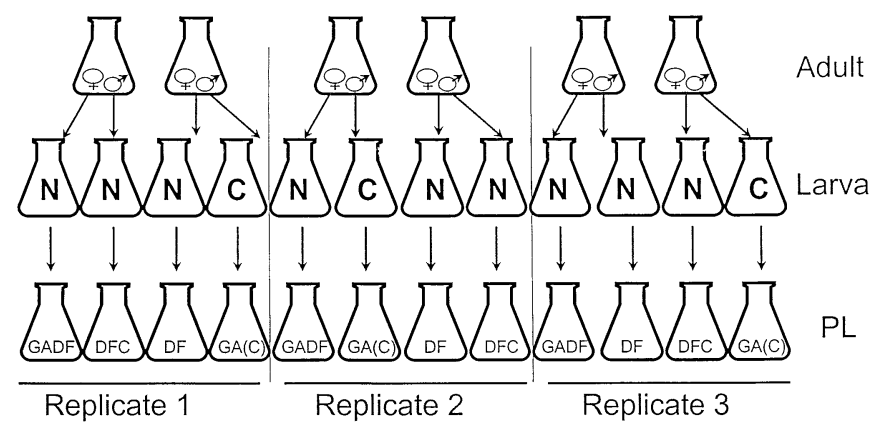

Fig. 1. Experimental design repeated in April and September. The April experiment consisted of 3 replicates, while the September experiment had only 2 replicates. During the larval phase, 1 treatment was fed on a diet containing Cocconeis neothumensis (C), while the other 3 treatments were fed on a diet without $C$. neothumensis (N). Each postlarval feeding experiment (PL) consisted of 4 treatments. In each replicate, the assignment of 2 treatments to the larvae produced by a single female was randomised. GADF = green algae + dry food fed to postlarvae of Hippolyte inermis; $\mathrm{DF}=$ dry food; $\mathrm{DFC}=$ test diet, composed of C. neothumensis + dry food; $\mathrm{GA}(\mathrm{C})=$ diet composed by green algae, fed to postlarvae of shrimps that received, during the larval phases, a diet containing C. neothumensis and (4) GA(C): Postlarvae fed on C. neothumensis during the larval development phase were then fed on green alga Enteromorpha sp.

The 4 treatments, for each of 3 replicates, were obtained by larvae produced by 2 females of Hippolyte inermis, following a semi-randomised experimental plan (Fig. 1). At the start of the postlarval experimental phase, surviving individuals in each flask were reduced to 40 , or higher (to avoid any influence on development due to density), and they were transferred to $1000 \mathrm{ml}$ flasks containing $800 \mathrm{ml}$ of $0.45 \mu \mathrm{m}$ filtered seawater and the selected food items. At $2 \mathrm{~d}$ intervals, postlarvae were collected by a $0.45 \mu \mathrm{m}$ net, counted, measured using a millimeter scale placed under a Petri dish, checked for their general conditions, and transferred to new flasks with the addition of clean water and food items, consistent with their diet treatment. This phase ended after about $45 \mathrm{~d}$ from hatching, when postlarvae achieved sexual maturation, at about 5 to $6 \mathrm{~mm}$ total length.

Analysis of sex. Sex and size were checked on narcotised shrimps under a binocular microscope, and identified by observing the shape and size of the first 2 pleopods. For this purpose, all shrimps were tested twice during the experiment, i.e. after 35 and $45 \mathrm{~d}$ from hatching. Narcotisation was devised (Smaldon \& Lee 1979) to avoid damage to the experimental shrimps. Each individual was immersed for about $30 \mathrm{~s}$ in a wellmixed solution of $0.1 \mu \mathrm{l}$ chloroform in $250 \mathrm{ml}$ of seawater. Narcotised shrimps were easily manipulated, so that the ventral side was visible, and their sexual maturation was assessed under a dissecting microscope $(40 \times)$. After sexual identification, shrimps were quickly transferred to a Petri dish with fresh seawater, where they recovered completely after a period of 30 to $90 \mathrm{~s}$.

After $45 \mathrm{~d}$, when most individuals had reached sexual maturity, all shrimps were preserved in $70 \%$ alcohol. Their second pleopods were excised under a binocular microscope and mounted on a slide for final determination of sex.

Statistical analyses. Linear regressions were applied to the shrimp size data, collected every $2 \mathrm{~d}$ throughout the experiment periods of both larval and postlarval growth. A growth curve was calculated for each treatment. The slopes obtained for each treatment were compared by ANCOVA (Sokal \& Rohlf 1995) to examine any difference in the growth of shrimps under different diet regimes.

To test whether the appearance of beta females was influenced by the diet, a McNemar's test (Sokal \& Rohlf 1995) was applied to the percentage of males and females in the different treatments, for each replicate. For this purpose, data obtained in the 3 postlarval treatments without diatoms 
(GADF, DF, GA(C)) were compared to the data obtained in the treatment with the presence of Cocconeis neothumensis, during the postlarval growth (DFC). Similarly, the data obtained in the 2 postlarval treatments without diatoms (GADF, DF) were compared to the data obtained in the treatment with the presence of C. neothumensis during the larval growth $(\mathrm{GA}(\mathrm{C}))$.

\section{RESULTS}

During the 2 field sampling periods (April and September), 71 and 57 adult individuals were collected, respectively. The size differences between individuals collected in April (females, average $21.00 \mathrm{~mm}$; males, $10.12 \mathrm{~mm}$ ) and in September (females, $17.80 \mathrm{~mm}$; males, $10.61 \mathrm{~mm})$ were not significant $(t$-test; $\mathrm{p}=$ 0.351). The size of females used for larval production was between 20 and $26 \mathrm{~mm}$ in April and between 14 and $20 \mathrm{~mm}$ in September. Therefore, all females cho-

Table 1. Results of the feeding experiments at Day 45. Total number of males (M), females (F) and juveniles $(\mathrm{J})$ is given for each replicate, treatment, and experimental period. Percent mortality was calculated from the start of postlarval treatments. Abbreviations of the 4 dietetic regimes are explained in the text

\begin{tabular}{|c|c|c|c|c|c|}
\hline & & \multicolumn{3}{|c|}{ Replicate } & \multirow[t]{2}{*}{ Mortality } \\
\hline & & 1 & 2 & 3 & \\
\hline \multicolumn{6}{|l|}{ April } \\
\hline \multirow[t]{3}{*}{ GADF } & M & 18 & 16 & 16 & \\
\hline & $\mathrm{F}$ & 0 & 0 & 1 & 52.50 \\
\hline & $\mathrm{J}$ & 2 & 2 & 2 & \\
\hline \multirow[t]{3}{*}{ DF } & M & 17 & 15 & 20 & \\
\hline & $\mathrm{F}$ & 2 & 1 & 2 & 50.00 \\
\hline & $\mathrm{J}$ & 0 & 2 & 1 & \\
\hline \multirow[t]{3}{*}{ DFC } & M & 5 & 6 & 6 & \\
\hline & $\mathrm{F}$ & 11 & 11 & 12 & 53.33 \\
\hline & $\mathrm{J}$ & 2 & 2 & 1 & \\
\hline \multirow[t]{3}{*}{$\mathrm{GA}(\mathrm{C})$} & M & 18 & 17 & 15 & \\
\hline & $\mathrm{F}$ & 0 & 1 & 2 & 45.54 \\
\hline & $\mathrm{J}$ & 3 & 3 & 2 & \\
\hline \multicolumn{6}{|c|}{ September } \\
\hline \multirow[t]{3}{*}{ GADF } & M & 16 & 17 & & \\
\hline & $\mathrm{F}$ & 1 & 1 & & 51.25 \\
\hline & $\mathrm{J}$ & 2 & 2 & & \\
\hline \multirow[t]{3}{*}{ DF } & M & 16 & 17 & & \\
\hline & $\mathrm{F}$ & 1 & 1 & & 49.33 \\
\hline & $\mathrm{J}$ & 1 & 2 & & \\
\hline \multirow[t]{3}{*}{$\mathrm{DFC}$} & M & 6 & 8 & & \\
\hline & $\mathrm{F}$ & 12 & 14 & & 46.25 \\
\hline & $\mathrm{J}$ & 2 & 1 & & \\
\hline \multirow[t]{3}{*}{$\mathrm{GA}(\mathrm{C})$} & M & 15 & 17 & & \\
\hline & $\mathrm{F}$ & 0 & 1 & & 49.33 \\
\hline & $\mathrm{J}$ & 2 & 3 & & \\
\hline
\end{tabular}

sen for larval production were alpha females. The size of males used for reproduction was between 8 and $12 \mathrm{~mm}$ in both April and September. The experimental system devised for reproduction and feeding of larvae was sufficient to obtain, on the whole, 3160 larvae, 1200 of which were used for feeding experiments in April and 800 in September. No aggressivity was observed between the 2 adult individuals reared in each flask. The colour of reared individuals, however, changed during the experiment, from greenish to whitish, according to the mimicry characterising this species (Bedini et al. 1997).

The production of larvae coincided consistently with the moult of females. The number of larvae produced by each female was highly variable, depending on both the season and the size of females. The maximum production was observed in April (237 larvae from a single female), the minimum in September (32). Mortality during the larval phase did not exceed $32 \%$ in all treatments, and during the postlarval phase was $49 \%$, on average (Table 1). The most critical period was represented by sex determination at Day 35, as not all narcotised individuals recovered. The $p$-value for the treatment by the covariate interaction (ANCOVA) was 0.820 , so the assumption of homogeneity of slopes is plausible (Table 2), although a slightly faster growth was obtained with the diet DFC (slope 0.15), while the slowest growth was obtained with the diet GA(C) (slope 0.10). The growth process was almost continuous, but larvae from all treatments exhibited a period of lower increase in length from Days 15 to 22. Length increases became greater after the settlement to postlarvae. On average, Hippolyte inermis exhibited an increase in length of $0.186 \mathrm{~mm} \mathrm{~d}^{-1}$ until Day 35 of the experiment. The maximum size, Day 45 of the experiment, was $10 \mathrm{~mm}$ total length, reached by postlarvae under GADF, GA(C) (April; Fig. 2) and DF (both April and September; Figs. $2 \& 3$ ) treatments.

The differences between sex ratio and size distributions obtained in April and September experiments, in each treatment, were not significant (Figs. $2 \& 3$; $t$-test, $\mathrm{p}>0.05)$, although the total number of adult individuals obtained at the end of the experiments in Septem-

Table 2. $\mathrm{R}^{2}$ and slopes of the growth curves obtained by linear regression of the size of individuals sampled within each treatment versus the time of experiment, until Day 45

\begin{tabular}{|lcc|}
\hline Treatment & $\mathrm{R}^{2}$ & Slope \\
\hline GADF & 0.966 & 0.13 \\
$\mathrm{DF}$ & 0.961 & 0.14 \\
$\mathrm{DFC}$ & 0.910 & 0.15 \\
$\mathrm{GA}(\mathrm{C})$ & 0.923 & 0.10 \\
\hline
\end{tabular}




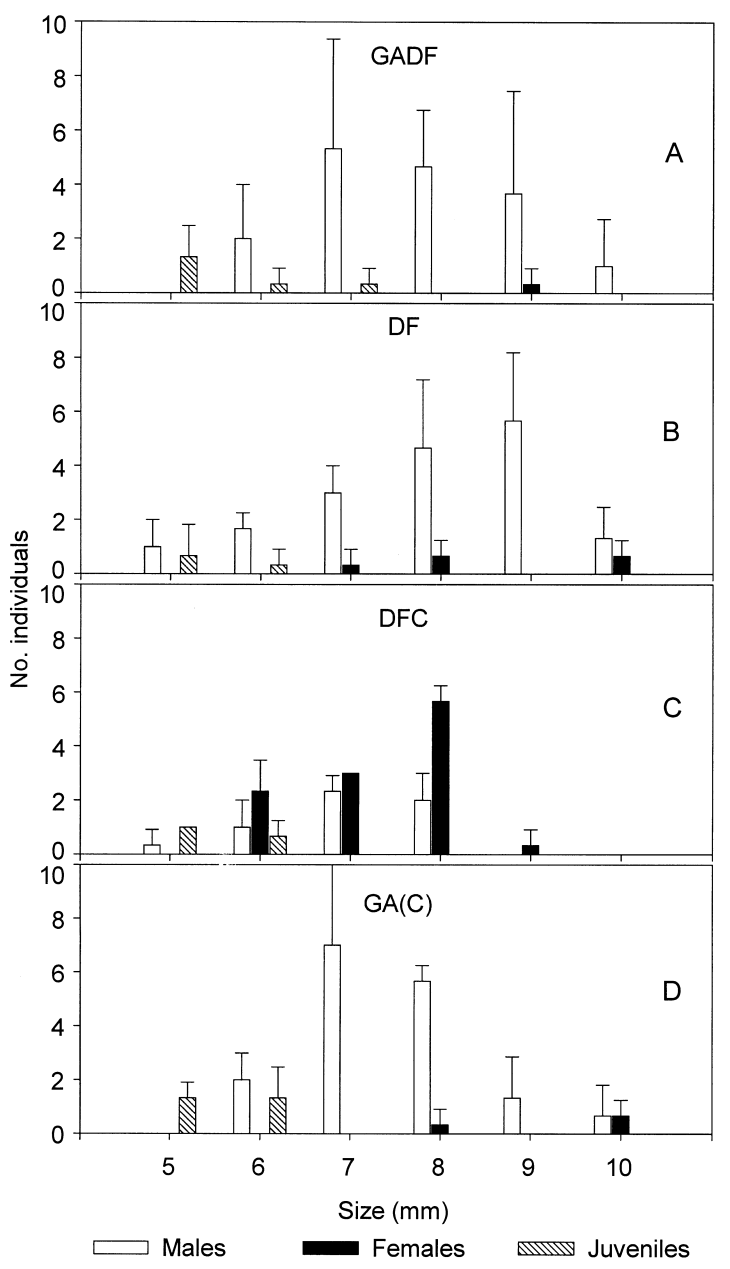

Fig. 2. Mean number $( \pm \mathrm{SD})$ of males, females and immature shrimps of each size class, obtained at the end (Day 45) of the April rearing experiment

ber (158) was lower than in April (234) due to the availability of only 2 replicates. The GADF treatment yielded only 1 female ( $9 \mathrm{~mm}$ total length) in the 3 replicates of April (Fig. 2A) and 2 females, of the same size, in the September experiment (Fig. 3A). This treatment yielded mostly males of between 7 and $9 \mathrm{~mm}$ total length, with the presence of a few immature ones between 5 and $7 \mathrm{~mm}$ at Day 45. The DF treatment yielded 5 females between 7 and $10 \mathrm{~mm}$ in April and 2 females between 8 and $10 \mathrm{~mm}$ in September. In this treatment a higher number of large males ( 8 to $9 \mathrm{~mm}$ ) was observed (Figs. 2B \& 3B). The DFC treatment yielded the largest abundance of females, both in April (35 ind.) and in September (26 ind.), between 5 and $9 \mathrm{~mm}$ (Figs. 2C \& 3C). In this treatment, only 5 males larger than $7 \mathrm{~mm}$ were found in September; all the other males were small. The GA(C) treatment yielded only 3 females in April and 1 small female $(5 \mathrm{~mm}$ total length) in September (Figs. 2D \& 3D).

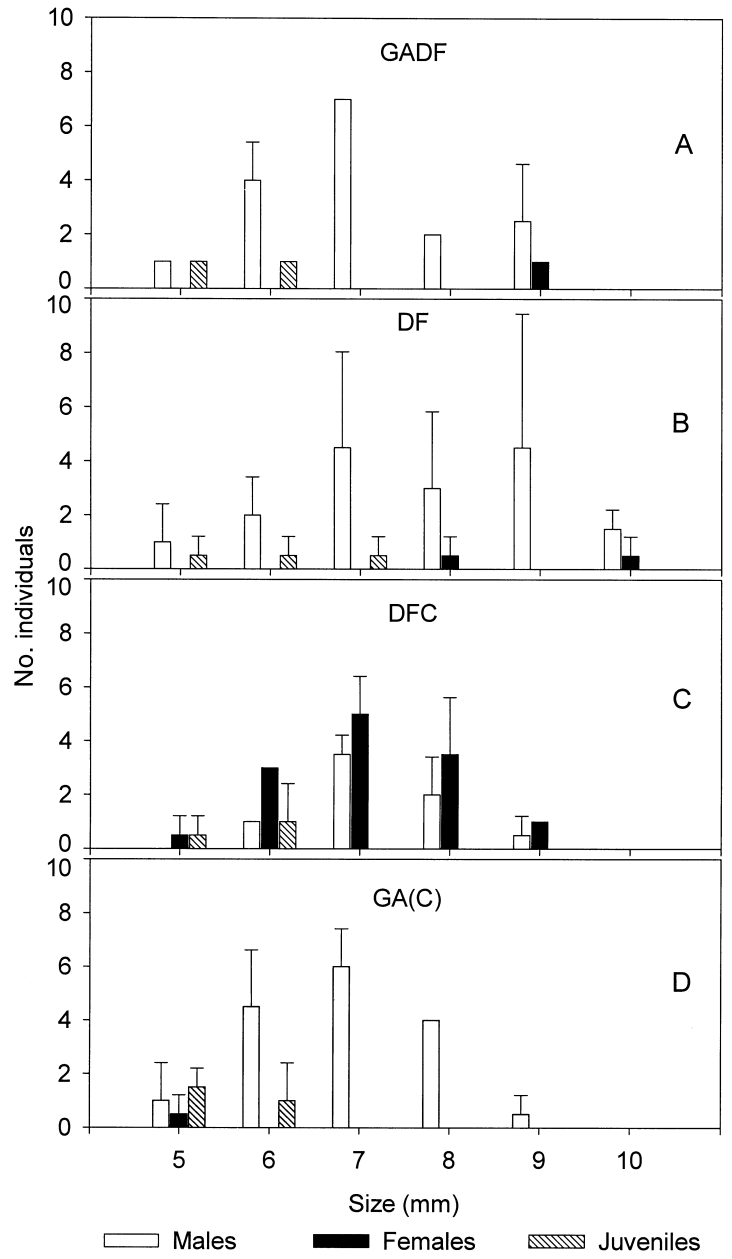

Fig. 3. Mean number $( \pm \mathrm{SD})$ of males, females and immature shrimps of each size class, obtained at the end (Day 45) of the September treatments

Striking differences between the DFC treatment and all the other treatments were observed by Day 35 of the experiments (Fig. 4). In both April and September the number of females at Day 35 was higher in the DFC treatment than the number of males and juveniles (Figs. 4A,C). The number of juveniles decreased considerably from Days 35 to 45 of the experiments, as most individuals reached sexual development (Fig. 4). The immature shrimps represented about $35 \%$ of individuals at Day 35 of the experiment, and decreased to about $10 \%$ of the total individuals at Day 45 . There was a significant difference (McNemar's test; $\mathrm{p}<$ 0.001 ) in the proportion of individuals between the postlarval treatment containing Cocconeis neothumensis (DFC) and all the other treatments (Table 1). Differences were significant $(p<0.001)$ for both experimental periods (April and September). No significant differences were detected between the results of the same treatment, when April and September data were 


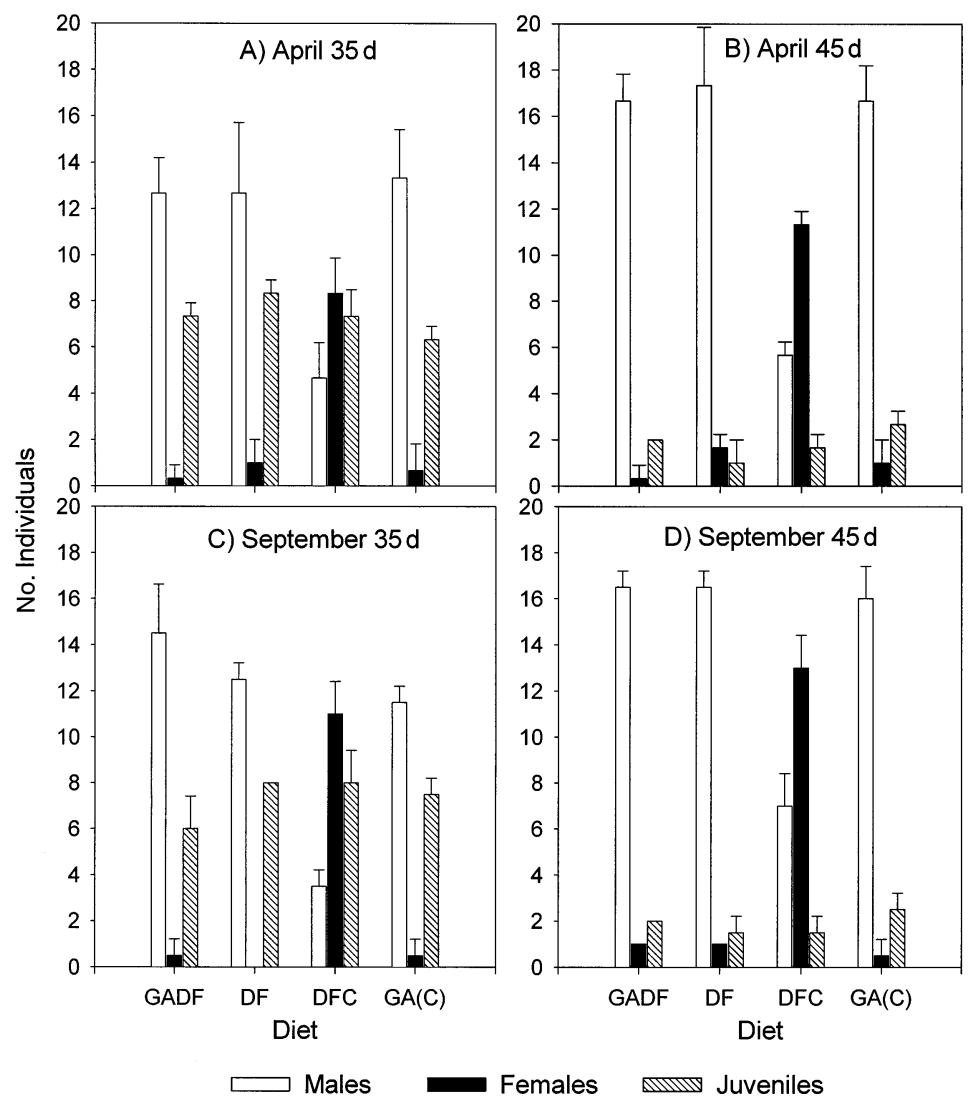

Fig. 4. Mean number $( \pm \mathrm{SD})$ of males, females and immature shrimps obtained in April at (A) Day 35 and (B) Day 45 of the experiment and in September at (C) Day 35 and (D) Day 45 of the experiment, for each treatment

compared. Pooling data from all the replicates, individuals on diets without $C$. neothumensis comprised $85.39 \%$ males, $5.06 \%$ females and $9.55 \%$ juveniles (Fig. 5A). Individuals on the diet containing C. neothumensis in the postlarval period comprised $30.36 \%$ males, $60.71 \%$ females and $8.93 \%$ juveniles (Fig. 5B). No significant differences were found between the treatment containing only $C$. neothumensis in the larval phase $(\mathrm{GA}(\mathrm{C}))$ and the 2 treatments containing no diatoms in the postlarval phase (GADF, DF).

\section{DISCUSSION}

Larval diets containing both plant and animal items (Regnault 1969a) resulted in a sufficient number of postlarvae for feeding experiments. In the laboratory, larvae reached sexual maturity on average $45 \mathrm{~d}$ after hatching at a mean size of $7 \mathrm{~mm}$. In contrast, field data indicated that shrimps may reach sexual maturity at $5 \mathrm{~mm}$, about $30 \mathrm{~d}$ after hatching (Zupo 1994). These differences may be explained by the higher variety of food items available in the field. Diet may also influence the succession of larval stages and development (Le Roux 1963), and the results of the present investigation confirm the importance of animal items in the diet of larvae (Provenzano 1967, Amat et al. 1987). Both the size distribution and the sex ratio of individuals of each treatment exhibited no significant differences between the experiments of April and September, thus demonstrating that, in consistent environmental conditions, the females sampled in the 2 periods produced a generation of similar characteristics.

The results indicated that sex reversal in Hippolyte inermis is influenced by ingested food. As demonstrated by the $\mathrm{GA}(\mathrm{C})$ treatment, food in the larval phase had no effect on sex differentiation, as no significant differences were observed between the treatment containing Cocconeis neothumensis during the larval phase and the other treatments not containing this diatom. In contrast, the results of the DFC treatment demonstrated a clear effect of diatoms consumed during the postlarval growth period, from Days 25 to 45 of the experiment. The abundance of females in the treatments not containing C. neothumensis during the postlarval growth period (GADF, DF and GA(C)) was as low as $5 \%$. This finding may explain the absence of beta females in the field in the September recruitment period (Zupo 1994), when the diatom is less abundant in the leaf canopy of Posidonia oceanica. The percent abundance of females in the treatment containing C. neothumensis (DFC) was 12 times higher than in all the other treatments, and may explain the abundance of beta females in the field during the April recruitment period, when diatoms of the genus Cocconeis reach their maximum abundance in the leaf canopy of $P$. oceanica (Mazzella $\&$ Ott 1984). These results are in accordance with the presence of Cocconeis in the gut contents of shrimps collected in the field in April (Zupo \& Mazzocchi 1998).

The higher abundance of small females in the treatment containing Cocconeis neothumensis was clear by Day 35, even though $35 \%$ of individuals were still in the juvenile phase (Fig. 4). It is thus unlikely that females observed at the end of the experiment had passed through a short male stage. Most individuals reached their sexual maturity before Day 35 from hatching, and all but $10 \%$ completed their sexual development between Days 35 and 45 after hatching. Moreover, females produced by the DFC treatment exhibited a small size $(7.3 \mathrm{~mm}$, on average), compara- 


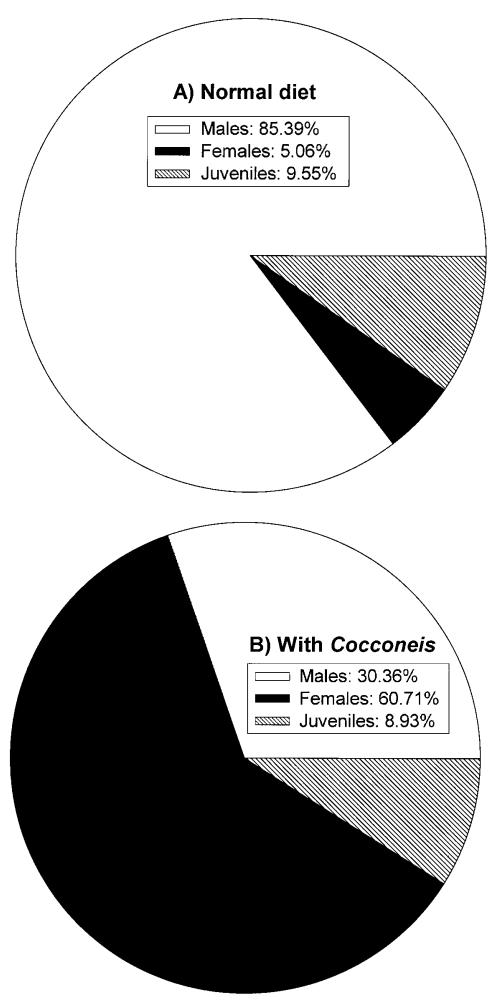

Fig. 5. Percent of males, females and immature shrimps obtained within the postlarval feeding treatments (A) without (GADF, GA(C), DF) Cocconeis neothumensis diatoms and (B) with (DFC) C. neothumensis. Data from all the replicates in both the experimental periods (April and September) were pooled

ble to the size of beta females detected in the natural populations in April (Zupo 1994).

Although growth was almost constant over the experimental period, as demonstrated by the good fit of linear regressions, larvae exhibited a short period of lower growth between Days 10 and 20 of the experiments. This may be due to the passage through complex developmental stages and to a requirement for selected food items (Le Roux 1963). The presence of Cocconeis neothumensis in the postlarval diet produced a good growth of shrimps. In fact, shrimps under the DFC treatment exhibited a larger mean size at Day 45 than shrimps fed the DF diet. The average size of females in the DFC treatment, however, was smaller than the size of females in all the other treatments. Therefore, the development of a female gonad may require energies which slow the normal growth process (Dutz 1998).

No information is available on a similar effect of food on other benthic crustaceans, although protandric hermaphroditism is a common strategy in several species of decapod crustaceans (Yaldwyn 1966, Gherardi \& Calloni 1993). It is well known that food may influence the hormone metabolism in several organisms, such as insects (Harrison 1990), copepods (Jònasdòttir 1994), shrimps (Yano 1995) and fish (Bell et al. 1996). However, it is still unclear whether the effects of diatoms on the sex reversal of Hippolyte inermis may be due to an influence of dietary components on the hormone metabolism, or to a direct effect on the gonadic tissues (Charniaux-Cotton 1958). In fact, in this species, female gonadic buds are absent (Reverberi 1950), and the female gonad is built, in adult males, starting from undifferentiated cells. Therefore, a direct influence of food substances with hormone activity on the female gonad may be negated, when the shrimp is still undifferentiated. Moreover, a lack of factors allowing the normal development could be excluded, when we consider that the growth rate in culture (about $4 \mathrm{~mm} \mathrm{mo}^{-1}$, on average) was higher than the average growth rate observed in the field (1.3 $\mathrm{mm} \mathrm{mo}^{-1}$; Zupo 1994). In contrast, sex reversal may be influenced in decapods by parasitic castration (Baffoni 1947), temperature (Allen 1959) or by the attainment of a given size (Noel 1973). $H$. inermis is sensitive to several environmental cues, at least during larval development (Regnault 1969b), and environmental factors may influence sex change in several crustaceans (Fleminger 1985, Arechiga \& Rodriguez-Sosa 1997) and affect the structure of phytal communities (Edgar 1983, 1990). However, identical experimental conditions characterised all the tests performed. Le Roux (1963) also hypothesised that the 'transitory stages' between the larval stage IV and the last zoea before the postlarva were a consequence of type and abundance of food, but our data indicate that the influence of Cocconeis neothumensis on sex reversal is limited to the postlarval period of development.

Diatoms have been demonstrated to influence the ecology and the life cycle of other crustaceans (Miralto et al. 1995, Dutz 1998). Egg production and hatching success in individuals of the copepod Centropages typicus decreased when diatoms were fed to adult females (Ianora et al. 1995). Diatoms of the genus Thalassiosira are able to arrest the embryonic development of the copepod Calanus helgolandicus (Poulet et al. 1994). The production by several species of diatoms of compounds detrimental to the development and survival of grazers may have major implications on secondary production (Miralto et al. 1996). However, in Hippolyte inermis, other effects (e.g. destruction of the male gonadic bud, allowing a direct development as female, or direct influence on the androgenic gland) could be possible (Hoffman 1969, Adiyodi \& Adiyodi 1970, Miralto et al. 1999), resulting from co-evolutionary processes. In fact, $H$. inermis is largely adapted to the life in Posidonia oceanica (d'Udekem d'Acoz 1996) and the pattern of abundance of alpha and beta females is synchronised with the seasonal abundance of micro- and 
macroalgae in the field (Zupo 1994). Therefore, the toxic effect of diatoms may be translated in this species into a spring signal for the development of beta females, as observed in other crustaceans (Svensen \& Tande 1999). It was demonstrated that the presence of beta females is a crucial factor in maintaining a constant sex ratio, allowing the September reproductive burst (Zupo 1994). Therefore, the presence of beta females in the spring population, triggered by the feeding on diatoms abundant in this season, may be an adaptive strategy (Bull 1987) to provide a sufficient number of females for the next mating period in September.

Acknowledgements. I am grateful to Dr D. Marino and Dr F. Esposito (Stazione Zoologica 'A. Dohrn'), for providing the phytoplankton cultures, and to Dr E. Conte, for providing the cultures of benthic diatoms. The company 'Ittica Ugento' provided living cultures of Brachionus plicatilis. Mr E. Rando performed the sampling operation in the field. M. Lorenti offered continuous technical support to the present research. R. De Maio offered his support for the devising and functioning of the thermostatic chamber. Dr M. C. Buia identified the macroalgae for shrimp feeding. Dr M. De Stefano cleaned and identified the cultured species of Cocconeis neothumensis using a SEM microscope. Dr S. Castagna took care of living cultures of larvae. Dr M. Scardi gave his advice in the statistical treatment of data. I am particularly indebted to Dr L. Mazzella, for scientific advice during the whole experimentation. Dr W. G. Nelson kindly reviewed the manuscript and gave invaluable suggestions for its improvement.

\section{LITERATURE CITED}

Adiyodi G, Adiyodi RG (1970) Endocrine control of reproduction in decapod crustacea. Biol Rev 45:121-165

Allen JA (1959) On the biology of Pandalus borealis Kroyer, with reference to a population off the Northumberland coast. J Mar Biol Assoc UK 38:189-220

Amat F, Hontoria F, Navarro JC, Gozalbo M (1987) Preliminary results on the nutritional value of Artemia salina nauplii for the decapod crustacean larvae in culture. In: Sarda F (ed) Third Colloquium Crustacea Decapoda Mediterranea. CSIR, Barcelona p 533-543

Aréchiga H, Rodriguez-Sosa L (1997) Coupling of environmental and endogenous factors in the control of rhythmic behaviour in decapod crustaceans. J Mar Biol Assoc UK $77: 17-29$

Baffoni GM (1947) Osservazioni sulla trasformazione del sesso nei Crostacei Decapodi. Pubbl Stn Zool Napoli 21(2):1-16

Bedini R, Canali MG, Baldi C (1997) Mimetismo criptico nei crostacei della prateria a Posidonia oceanica (L.) Delile. Biol Mar Medit 4(1):353-355

Bell MV, Dich JR, Thrush M, Navarro JC (1996) Decreased 20: 4 -6/20:5n-3 ratio in sperm from cultured sea bass, $D i-$ centrarchus labrax, broodstock compared with wild fish. Aquaculture 144:189-199

Buia MC, Zupo V, Mazzella L (1992) Primary production and growth dynamics in Posidonia oceanica. PSZN I: Mar Ecol 13:2-16

Bull JJ (1987) Sex determining mechanisms: an evolutionary perspective. In: Stearns SC (ed) The evolution of sex and its consequences. Birkhaeuser Verlag, Basel, p 93-114
Charniaux-Cotton H (1958) Contrôle de la différenciation du sexe et de la reproduction chez les Crustacés supérieurs. Bull Soc Zool Fr 83:314-336

d'Udekem d'Acoz C (1996) The genus Hippolyte Leach 1814 (Crustacea: Decapoda: Caridea: Hippolytidae) in the East Atlantic Ocean and the Mediterranean Sea, with a checklist of all species in the genus. Zool Verh (Leiden) 303: $1-133$

Dutz J (1998) Repression of fecundity in the neritic copepod Acartia clausi exposed to the toxic dinoflaggellate Alexandrium lusitanicum: relationship between feeding and egg production. Mar Ecol Prog Ser 175:97-107

Edgar GJ (1983) The ecology of South-East Tasmanian phytal animal communities. II. Seasonal change in plant and animal populatons. J Exp Mar Biol Ecol 70:159-179

Edgar GJ (1990) The influence of plant structure on the species richness, biomass and secondary production of macrofaunal assemblages associated with Western Australia seagrass beds. J Exp Mar Biol Ecol 137:215-240

Fernández-Munoz R, García-Raso JE (1987) Study of a population of Alpheus dentipes Guérin, 1832 from calcareous bottoms in Southern Spain. Invest Pesq 51(1):343-359

Fleminger A (1985) Dimorphism and sex change in copepods of the family Calanidae. Mar Biol 88:273-294

Gambi MC, Lorenti M, Russo GF, Scipione MB, Zupo V (1992) Depth and seasonal distribution of some groups of vagile fauna of the Posidonia oceanica leaf stratum: structural and trophic analyses. PSZN I: Mar Ecol 13:17-39

Gherardi F, Calloni C (1993) Protandrous hermaphroditism in the tropical shrimp Athanas indicus (Decapoda: Caridea), a symbiont of sea urchins. J Crustac Biol 13(4):675-689

Guillen Nieto JE (1990) Guia illustrada de los crustaceos decapodos del litoral alicantino. Instituto del Cultura 'Juan Gil-Albert', Alicante

Gutiérrez-Yurrita PJ, Sancho G, Bravo MA, Baltanas A, Montes C (1998) Diet of the red swamp crayfish Procambarus clarkii in natural ecosystems of the Doñana National Park temporary fresh-water marsh (Spain). J Crustac Biol 18:120-127

Harrison KE (1990) The role of nutrition in maturation, reproduction and embryonic development of decapod crustaceans: a review. J Shellfish Res 9:1-28

Hoffman DL (1969) The development of the androgenic glands of a proterandric shrimp. Biol Bull 137:286-296

Ianora A, Poulet SA, Miralto A (1995) A comparative study of the inhibitory effect of diatoms on the reproductive biology of the copepod Temora stylifera. Mar Biol 121: 533-539

Jònasdòttir SH (1994) Effects of food quality on the reproductive success of Acartia tonsa and Acartia hudsonica: laboratory observations. Mar Biol 121:67-81

Keller D, Claus W, Guillard RL (1987) Media for the culture of oceanic ultraphytoplankton. J Phycol 23:633-638

Le Roux A (1963) Contribution à l'étude du développement larvaire d'Hippolyte inermis Leach (Crustacée Décapode Macroure). C R Acad Sci Paris 256:3499-3501

Mazzella L, Buia MC (1989) Variazioni a lungo termine in alcuni parametri strutturali di una prateria a Posidonia oceanica. Nova Thalassia 10(1):533-542

Mazzella L, Ott J (1984) Seasonal changes in some features of Posidonia oceanica (L.) Delile leaves and epiphytes at different depths. In: Boudouresque CF, Jeudy de Grissac A, Olivier J (eds) International Workshop on Posidonia oceanica Beds. GIS Posidonie, Marseille, p 119-127

Mazzella L, Scipione MB, Gambi MC (1989) Spatio-temporal distribution of algal and animal communities in a Posidonia oceanica meadow. PSZN I: Mar Ecol 10(2):107-129 
Miralto A, Ianora A, Poulet SA (1995) Food type induces different reproductive responses in the copepod Centropages typicus. J Plankton Res 17:1521-1534

Miralto A, Ianora A, Poulet SA, Romano G, Laabir M (1996) Is fecundity modified by crowding in the copepod Centropages typicus? J Plankton Res 18:1033-1040

Miralto A, Barone G, Romano G, Poulet SA, Ianora A, Russo GL, Buttino I, Mazzarella G, Laabir M, Cabrini M, Giacobbe MG (1999) The insidious effect of diatoms on copepod reproduction. Nature 402:173-176

Nelson WG (1981) The role of predation by decapod crustaceans in seagrass ecosystems. Kiel Meeresforsch 5: 529-536

Noel P (1973) Cycle biologique et inversion sexuelle du Crustacé Décapode Natantia Processa edulis. Cah Biol Mar 14: 217-227

Poulet SA, Ianora A, Miralto A, Meijer L (1994) Do diatoms arrest embryonic development in copepods? Mar Ecol Prog Ser 111:79-86

Provasoli L (1963) Growing marine seaweeds. Proc Int Seaweed Symp. Pergamon Press, Oxford, p 9-17

Provenzano AJ Jr (1967) Recent advances in the laboratory culture of decapod larvae. Proc Symp Crustac II:940-945

Regnault M (1969a) Etude experimentale de la nutrition d'Hippolyte inermis Leach (Decapoda, Natantia) au course de son developpement larvaire, au laboratoire. Int Rev Ges Hydrobiol 54:749-764

Regnault M (1969b) Influence de la temperature et de l'origine de l'eau de mer sur le développement larvaire au laboratoire d'Hippolyte inermis Leach (Décapode-Natantia). Vie Milieu 20:137-152

Regnault M (1969c) Recherche du mode de nutrition d'Hippolyte inermis Leach (Decapoda, Caridea) au début de sa vie larvaire: structure et role des pièces buccales. Crustaceana 17(3):253-264

Editorial responsibility: Otto Kinne (Editor),

Oldendorf/Luhe, Germany
Reverberi G (1950) La situazione sessuale di Hippolyte viridis e le condizioni che la reggono. Boll Zool 4-6:91-94

Rice AL, Williamson DI (1970) Methods for rearing larval decapod Crustacea. Helgol Wiss Meeresunters 20: 417-434

Smaldon G, Lee EW (1979) A synopsis of methods for the narcotisation of marine invertebrates. Royal Scottish Museum, Edinburgh

Sokal RR, Rohlf FJ (1995) The principles and practice of statistics in biological research. WH Freeman \& Co, New York

Svensen C, Tande K (1999) Sex change and female dimorphism in Calanus finmarchicus. Mar Ecol Prog Ser 176: 93-102

Veillet A, Dax J, Vouax AM (1963) Inversion sexuelle et parasitisme par Bophyrina virbii (Walz) chez la crevette Hippolyte inermis (Leach). C R Acad Sci Paris 256:790-791

Yaldwyn JC (1966) Protandrous hermaphroditism in decapod prawn of the families Hippolytidae and Campilonotidae. Nature 209:1366-1378

Yano I (1995) Final oocyte maturation, spawning and mating in penaeid shrimp. J Exp Mar Biol Ecol 193:113-118

Zariquiei Alvarez R (1968) Crustaceos Decapodos ibericos. Invest Pesq 32:1-510

Zupo V (1994) Strategies of sexual inversion in Hippolyte inermis Leach (Crustacea, Decapoda) from a Mediterranean seagrass meadow. J Exp Mar Biol Ecol 178: $131-145$

Zupo V, Fresi E (1985) A study on the food web of the Posidonia oceanica (L.) Delile ecosystem: analysis of the gut contents of decapod crustaceans. Rapp Comm Int Exp Sci Mer Médit 29:189-192

Zupo V, Mazzocchi MG (1998) New perspectives in the investigation of food webs in benthic and planktonic coastal ecosystems. Biol Mar Medit 5(1):12-26

Submitted: August 23, 1999; Accepted: January 27, 2000 Proofs received from author(s): * 